НАУКОВИЙ ВІСНИК

Sentific messenger of Lviv National University of

7

(2)

औरा है

1 is 1 if

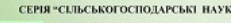

Том 22 № 92
Науковий вісник Дьвівського національного університету ветеринарної медицини та біотехнологій імені С.3. Гжицького. Серія: Сільськогосподарські науки

Scientific Messenger of Lviv National University of Veterinary Medicine and Biotechnologies. Series: Agricultural sciences

UDC 636.32/38:591.16.612.063

\title{
Cryopreservation of ram-sires semen with usage of synthetic extenders
}

\author{
K. Hrymak \\ Institute of Animal Biology NAAS, Lviv, Ukraine
}

Article info

Received 05.02.2020

Received in revised form 04.03 .2020

Accepted 05.03.2020

Institute of Animal Biology NAAS V. Stus Str., 38, Lviv,

79034, Ukraine.

Tel.: +38-093-235-95-55

E-mail:phm89@ukr.net
Hrymak, K. (2020). Cryopreservation of ram-sires semen with usage of synthetic extenders. Scientific Messenger of Lviv National University of Veterinary Medicine and Biotechnologies. Series: Agricultural sciences, 22(92), 62-70. doi: 10.32718/nvlvet-a9211

The retrospective analysis of the invention of synthetic extender for ram's semen cryopreservation, developed by different authors, is presented in the article. It has been shown, that in order to ensure the biological usefulness of the extenders for semen, they should contain phospholipids, electrolytes, nonelectrolytes, cryoprotectants, biologically active substances and other ingredients, due to the many physical and chemical processes that occur in the process of cooling and deep freezing of spermatozoa. Researchers have established the protective role of phospholipids from chicken egg in protecting sperm from cold stroke. It has been proven that the usage of dried yolk and egg powder in extenders during the cryopreservation of sperm provides a high protective effect of sperm at the level of natural yolk. The degree of effectiveness of different electrolytes in preventing cold shock has been indicated. Their protective function not only for the creation of buffer properties of extender, but also for the reduction of freezing point of aqueous solutions has been emphasized. The importance of sugars in the composition of ram's semen cryopreservation extenders has been proven. They reduce the conductivity of semen, thereby reducing sperm agglutination, act as antioxidants, inactivate spermolysins, increase the viscosity, structure water, prevent excessive hydration of proteins and organelles are used by sperm for respiration and glycolysis. It has been experimentally proven by a number of researchers, who studied the protective effect of antioxidants for the development of synthetic extender, that the process of cryopreservation intensifies the lipids peroxidation, which disrupts the orderliness of the sperm membranes structure and thereby the oxidation products damage the plasma membrane and adversely affect on the energy of sperm. A perspective direction in the development of new extenders for animal reproduction biotechnology has been highlighted, both for in vitro fertilization of oocytes and for freezing and thawing of semen using the metal nanoparticles.

Key words: ram-sires, semen, synthetic extender, ingredients, cryopreservation, fertilization capacity, metal nanoparticles.

\section{Кріоконсервування сперми баранів-плідників за використання синтетичних середовищ}

\author{
Х. М. Гримак
}

Інститут біології тварин НААН, м. Львів, Украӥна

У статті представлено ретроспективний аналіз розробки різними авторами синтетичних середовищ для кріоконсервування сперми баранів-плідників. Показано, щчо середовища для забезпечення біологічної повноцінності сперміїв повинні містити фосфоліпіди, електроліти, неелектроліти, кріопротектори, біологічно активні речовини та інші інгредієнти, цчо обумовлено багаточисельністю фізико-хімічних прочесів які проходять у сперміях за охолодження та глибокого заморожування. Дослідниками встановлена захисна роль фосфоліпідів курячого яйця у захисті спермїв від холодового удару. Доведено, щзо застосування сухого жовтка та яєчного порошку у середовищах, за кріоконсервування сперми, забезпечує високу захисну дію сперміїв на рівні натурального жовтка. Вказана ступінь ефективності різних електролітів у попередженні холодового удару. Підкреслено, щзо захисна їх функція полягає не тільки у створенні буферних властивостей середовищ, але і у зниженні точки замерзання водних розчинів. Підкреслено важливе значення цукрів у складі середовищ для кріоконсервування сперми баранів-плідників, які знижують електропровідність сперми, тим самим зменшують аглютиначію спермїв, діють як антиоксиданти, інактивують спермолізини, підвищують 
в 'язкість середовища, а також структурують воду, запобігають надмірній гідрації білків і органел та використовуються сперміями для дихання і гліколізу. Експериментально доведено рядом дослідників, які вивчали захисну дію антиоксидантів для розробки синтетичних середовищ, щуо прочес кріоконсервування інтенсифікує перокисне окиснення ліпідів внаслідок чого порушується упорядкованість структури мембран спермїв, а утворені при цььому продукти окиснення пошкоджують плазматичну мембрану $і$ негативно впливають на енергетику сперміїв. Відмічено перспективний напрям у розробиі нових середовиш у біотехнологї відтворення тварин, як для запліднення ооцитів іп vitro, так і для заморожування і розморожування сперми плідників з використанням наночастинок металів.

Ключові слова: барани-плідники, сперма, синтетичне середовище, інгредієнти, кріоконсервування, запліднювальна здатність, наночастинки металів.

\section{Вступ}

Збереження життєздатності сперміїв поза організмом грунтується на явищі анабіозу, яке залежить від складу синтетичних середовищ. Середовища для зберігання біологічної повноцінності сперміїв та їх кріоконсервування повинні уміщувати неелектроліти, електроліти, фосфоліпіди, кріопротектори, біологічно активні речовини і інші інгредієнти. Це обумовлено багаточисельністю фізико-хімічних процесів, що проходять у сперміях за охолодження і подальшого їх заморожування (Nauk, 1991).

Відомо, що сольові компоненти середовищ захищають сперміїв у діапазоні температур до $0{ }^{\circ} \mathrm{C}$, а цукри, полісахариди і гліцерин за температури нижче $0{ }^{\circ} \mathrm{C}$ (Ostashko, 1978; Platov, 1986).

За результатами досліджень ряду авторів важливу роль у захисті сперміїв від холодового удару відіграє жовток курячого яйця. Його кріозахисна дія полягає у властивості лецетину проникати у спермії і знижувати точку плавлення ліпідів (Milovanov, 1959; 1960; 1970). У практичних умовах глибокого заморожування сперми баранів-плідників жовток курячого яйця вводять синтетичне середовище у концентрації 10-20 \% (Tervit, 1984; Platov, 1986; Zheltobryuh, 1986).

В. К. Миловановим, I. I. Соколовською (Milovanov, 1959) була виявлена захисна роль фосфатидів курячого жовтка, які становлять лише $3 \%$ від всього об'єму жовтка. На основі цього автори рекомендували фосфатидні середовища для практичного застосування за штучного осіменінні тварин. Доведено, що сильніший захисний вплив мали жовтки яєць кур у раціоні яких були легкоплавкі жири і зелена трава.

Е. М. Платов (Platov, 1973; 1986), Ф. І. Осташко (Ostashko, 1978) вважають, що фосфоліпіди курячого яйця утворюють із плазматичною мембраною сперміїв іонні або водородні зв'язки. Їх захисна дія обумовлена утворенням на поверхні сперміїв гідрофобної фази, внаслідок якої сповільнюється осмотичний i дифузний обмін між середовищем і клітиною.

За аналізу дії на сперміїв баранів-плідників деяких фосфоліпідів, зокрема: фосфатиди холіну, фосфатиди летаноламіну та фосфатиди лінозитолу встановлено, що лише фосфатидилхолін зв'язується із плазматичною мембраною (Evans \& Setchell, 1978). Водночас вивчення кріозахисної дії на спермії баранів ліпопротеїдів одержаних із бобів сої, гомогенату плодів обліпіхи, ікри минтая і лосося виявлено, що вони володіють значно слабшою захисною дією, ніж натуральний жовток курячого яйця (Semyonova, 1987). Проте, застосування сухих яйцепродуктів, а саме: сухого жовт- ка і яєчного порошку, при кріоконсервуванні сперми баранів-плідників забезпечує високу захисну дію сперміїв на рівні натурального жовтка (Erohin et al., 1989).

Окрім ліпідів кріозахисну дію на сперміїв мають різні білки, зокрема: альбумін, казеїн, білки курячого жовтка та інші. Захисний вплив білків на сперміїв здійснюється їх властивістю з'єднувати токсичні іони металів (Nauk \& Guskov, 1983; Erohin et al., 1983; Smith et al., 1984; Platov, 1986). У науковій літературі $\epsilon$ повідомлення, що додавання у середовище для заморожування сперми сироватки крові сприяло підвищенню заплідненості овець за штучного осіменіння.

Важливе значення у синтетичних середовищах для кріоконсервування сперми баранів-плідників належить електролітам таким як трис оксиметиламінометану і двохнатрієвої солі етилендиамінтетраоцтової кислоти та іншим, які стабілізують рН у спермі за іiі охолодження та заморожування. Одночасно вони здійснюють антиоксидантний вплив на сперміїв (Saacke et al., 1968; Nauk, 1991; Erohin, 1994).

В. М. Давиденко (Davidenko, 1977), L. Fornusek et al. (Fornusek et al., 1981) стверджують, що сперма баранів краще переносить кріоконсервування у цукрово-жовткових середовищах із додаванням невеликої кількості електролітів, зокрема трис-буфер лимоннокислий натрій та інші.

Н. А. Желтебрюх і ін. (Zheltobryuh, 1977) також повідомили про високу активність і виживаність сперміїв баранів при заморожуванні яких у цукровожовткове середовище додавали трис-буфер (2-аміно 2-гідроксилметил - 1,3 пропандіол).

Оцінюючи придатність трьох середовищ для кріоконсервування сперми баранів-плідників, а саме: трис-цитратно-фруктозне, лактозо-жовточне і рафінозо-лактозо-жовткове P. Mesanos (Mesanos, 1977) довели, що найвищу активність і виживаність деконсервованих сперміїв забезпечило трис-цитратно-фруктозне середовище.

Таким чином, проведеними дослідженнями з виявлення впливу різних електролітів на спермії баранів при глибокому заморожуванні встановлена ступінь їх ефективності у попередженні холодового удару. Захисна дія електролітів полягає не тільки у створенні буферних властивостей середовищ, але й у зниженні точки замерзання водних розчинів (Belous et al., 1987).

Не менш важливе значення у складі середовища мають цукри (глюкоза, лактоза, глікокол). Вони як не електроліти знижують електропровідність сперми, тим самим зменшують аглютинацію сперміїв, діють як антиоксиданти, інактивують спермолізини, підви- 
щують в'язкість середовища. Крім того вони структурують воду, запобігають надмірній гідратації білків і органел та використовуються сперміями для дихання і гліколізу (Platov, 1986; Kurbatov et al., 1988; Nauk, 1991). У зв’язку з тим, було запропоновано вводити у середовища для заморожування сперми баранівплідників різні цукри. Кращі результати були одержані за використання сахарози чи лактози або комплексного їх застосування (Marinov, 1983; Belous et al., 1987; Epishina, 2009).

За аналізу різних синтетичних середовищ для розбавлення сперми баранів В. М. Давиденок із співавторами (Davidenko, 1977) встановили, що найпридатнішим виявилося рафінозо-цитротно-жовткове середовище, яке забезпечило активність деконсервованої сперми на рівні 3,5 бала та запліднювальну здатність сперміїв в межах 39,8 відсотка. Тип цукрів внесених у синтетичне середовище значно впливає на виживаність сперми. Одні дослідники вважають, що глюкоза $\epsilon$ кращим компонентом у середовищі, ніж фруктоза і рафіноза. Другі (Platov, 1965; Nauk, 1972) стверджують, що введення у середовище для заморожування сперми баранів лактози ефективніше впливає на якісні показники деконсервованої сперми порівняно 3 використанням глюкози чи рафінози.

Проте, В. К. Милованов, I. І. Соколовская (Milovanov \& Sokolovskaya, 1980) експериментально довели, що ізотонічний розчин сахарози ефективніше оберігає акросами сперміїв від набухання. Застосування глюкози у середовищах для кріоконсервування сперми на їх переконання не бажане, так як вона викликає бурхливий гліколітичний процес не тільки у плазмі сперми але і безпосередньо у самих сперміях. Це у свою чергу приводить до нагромадження молочної кислоти та зсуву рН у кислу сторону.

Е. М. Платовим, А. С. Волковим (Platov \& Volkov, 1979) було запропоновано двохступінчасте розбавлення сперми баранів-плідників 3 використанням багатокомпонентного цукрово-жовткового середовища із вмістом у ньому полісахариду гуміарабіку. За даними авторів гуміарабік, адсорбується на поверхні сперміїв і утворює шар структурованої води навколо сперміїв, тим самим оберігає їх від згубного контакту iз водою. Гуміарабік знижує евтектичну точку солей i у 125 разів сильніше зневоднює живі клітини, ніж сахароза. Заплідненість овець, осімінених спермою кріоконсервованою у середовищі з вмістом гуміарабіка становила 55-60 відсотка (Platov et al., 1980). Однак, виробничою перевіркою цього методу, опубліковані дані не були підтвердженні.

А. Н. Варнавський, В. А. Варнавская (Varnavskiy \& Vernavskaya, 1980; Varnavskiy et al., 1989) вказують про задовільні якісні показники деконсервованої сперми баранів-плідників, зокрема ії активності, резистентності, виживаності за використання трис-глюкозотокоферолового середовища. У якому в якості сильного буфера представлено трис-оксиметил аміном етан; неелектроліту - сахароза; для підтримки гліколізу сперміїв - глюкоза і у якості антиоксиданта - токоферол. Склад компонентів такого середовища забезпечує необхідний осмотичний тиск, зв’язує іони кальція у комплексний зв'язок, захищає оболонку сперміїв від проникнення різних катіонів і згубної дії одновалентних аніонів.

За даними К. Т. Касимова i iн. (Kasimov \& Ashimov, 1975), I. Н. Шайдуллина (Shaydullin, 1977), В. К. Милованова і ін. (Shaydullin \& Milovanov, 1981) найраціональнішими виявились синтетичні середовища виготовлені на ізотонічному розчині сахарози (цукру-рафінаду) з невеликим добавленням 20 \% ізотонічного розчину, кальцієвого комплексоетилендіамінтетраоцтового натрію та антиоксиданта токоферолу; бутокситалуолу, ди-трет-бутил-крезолу і ехінохрому та вмісту жовтка курячого яйця до 4-5 \%, гліцерину - до 4 відсотка.

Е. М. Платов і ін. (Platov et al., 1986), А. С. Ерохин (Erohin, 1994) повідомили про достатньо високу заплідненість овець осімінених деконсервованою спермою баранів-плідників замороженою у гліцеринжовтково-вуглевоно-комплексотарно-трис-буферному середовищі із застосуванням полісахариду декстрину. Автори вважають, що позитивна дія декстрину у середовищі за кріоконсервування пов'язана із його властивістю підвищувати в'язкість розчинів, що затруднює взаємодію іонів багатовалентних металів з субстратом окиснення у плазматичних мембранах сперміїв і тим самим інгібувати вільнорадикальне окиснення ліпідів.

За розробки синтетичних середовищ ряд дослідників вивчали захисну дію антиоксидантів. Пероксидне окиснення ліпідів являє собою багатоступінчастий процес ланцюгових окисних i вільнорадикальних реакцій, внаслідок чого утворюється багато біологічно активних сполук, а саме: вільні радикали, перекисі ліпідів та їх метаболіти. Основними факторами біологічних пошкоджень $є$ вільні радикали, тобто частинки, які мають спарений електрон і через те легко вступають у хімічну взаємодію. Крім того, продукти глибокого окиснення ліпоперекесей, зокрема альдегіди, кетони, кислоти, теж можуть бути токсичними для сперміїв. Водночас відомо, що у самій спермі самців знаходяться ендогенні антиоксиданти-фосфоліпіди, токофероли, коєнзим Q, глютатіон, цистин, вітамін Е і інші, які захищають сперміїв від перокисного окиснення ліпідів. А у самих клітинах знаходяться специфічні антиоксидантні ферменти: супероксиддисмутаза, глютатіонпероксидаза, глютатіонредуктаза і каталаза (Nauk \& Guskov, 1983; Platov, 1986; Vladimirov \& Sherstnev, 1989; Nauk, 1991; Vladimirov \& Potapenko, 2006; Vladimirov \& Proskurina, 2009).

Процес заморожування інтенсифікує пероксидне окиснення ліпідів внаслідок чого порушується упорядкованість структури мембран сперміїв. Продукти окиснення пошкоджують плазматичну мембрану i негативно впливають на енергетику сперміїв (Jones \& Mann, 1973). В. К. Милованов і інші (Milovanov et al., 1989) для інгібування пероксидного окиснення ліпідів сперми баранів-плідників запропонували іiі заморожувати в атмосфері нейтральних газів, зокрема: азоту, водню, гелію. У зв'язку із трудомісткістю цей метод не був впроваджений у виробництво.

Задовільні результати заморожування сперми баранів були одержані за використання у складі середовищ різних жиророзчинних антиоксидантів таких як: 
ди-трет-бутил-крезолу, бутилокситолуолу, ехінохрому, вітаміну Е. За їх застосування у складі середовищ для кріоконсервування сперми встановлено підвищення активності деконсервованих сперміїв та їх запліднювальної здатності. Гідрофобні антиоксиданти, зокрема бутилокситолуол і вітамін Е підвищують стійкість сперміїв до холодового удару. Ряд дослідників вважає, що захисна дія вищевказаних речовин зв'язана $з$ їх впливом на стан мікровязкості плазматичних мембран сперміїв (Shaydullin, 1980; Milovanov et al., 1983). Водночас P. F. Watson, W. J. Anderson (Watson \& Anderson, 1983) повідомили про низьку кріозахисну дію бутилоокситолуолу на сперму баранів-плідників.

За даними А. С. Ерохина (Erohin, 1994) введення у середовище для кріоконсервування сперми баранівплідників синтетичних водорозчинних антиоксидантів зокрема: анфен-натрію і феноксану позитивно не вплинуло на активність та виживаність деконсервованих сперміїв. Автор вважає, що гідрофобні антиоксиданти за кріоконсервування очевидно не являються перепоною процесам перекисного окиснення ліпідів у мембранах і внутрішніх структурах сперміїв. Одночасно А. М. Гуськов та ін. (Guskov et al., 1993) повідомили про позитивний вплив водорозчинних антиоксидантів на якісні показники деконсервованих сперміїв. А. Н. Варнавський та ін. (Varnavskiy \& Vernavskaya, 1980; Varnavskiy et al., 1989) запропонували гомогенат соку моркви, як антиоксиданта, за кріоконсервування сперми баранів-плідників. Його введення у кріосередовище забезпечило ягніння вівцематок на рівні застосування бутилокситолуолу 53 83 відсотка.

В. К. Милованов та ін. (Milovanov et al., 1983) вивчаючи кріозахисну дію різних каротиноїдів у складі середовищ для заморожування сперми баранівплідників, зокрема: фукоксантину, ß-каротину та каротиноїдії із шафрану встановили, що після штучного осіменіння вівцематок деконсервованою спермою ягніння у контрольній групі тварин склало 39 \%, а із додаванням у середовище вищевказаних каротиноїдії відповідно 58, 5451 відсотка. Проте, інші дослідники за введення у середовище для кріоконсервування сперми баранів каротиноїдів не виявили позитивного впливу на якість замороженої сперми, навпаки у деяких дослідженнях відмічено зниження активності та виживаності деконсервованих сперміїв (Marinov, 1983).

Рядом вчених доведено, що за кріоконсервування сперми самців у статевих клітинах проходить окиснення сільфгідрильних груп білків і низькомолекулярних тиолів, це призводить до пошкодження мембраних білків, інактивацію ряду ферментів та порушення енергетичних процесів у сперміях. Одночасно експериментально підтверджено, що введення у склад синтетичних середовищ для заморожування сперми низькомолекулярних тиолових сполук, в тому числі глутатіону, унітіолу, цистеїну, значно знижує окиснення сульфгідрильних груп і покращує якісні показники деконсервованих сперміїв баранів і бугаїв, зокрема: підвищує їх виживаність, знижує кількість пошкоджених акросом, стабілізує вміст сульфгідрильних груп і активність лактатдегідрогенази (Korban et al., 1983; Kurbatov et al., 1988; Moroz, 1990; Erohin et al., 1997).

Деякі дослідники для підвищення запліднювальної здатності деконсервованої сперми пропонували зменшувати ступінь іiі розбавлення перед заморожуванням. Проте, ефективність використання сперми виявилась дуже низькою (Wisser \& Salamon, 1974; Volkov, 1974; Zheltobryuh \& Ivahnenko, 1977; Kushnir, 1989).

У літературних джерелах наявні дані про важливе значення металів у процесі метаболізму статевих клітин самців і підвищенні стійкості сперміїв за їх кріоконсервування. Відомо, що у склад ферментів які каталізують реакції переносу хімічно активних груп, окислювально-відновні та гідролітичні процеси входять іони калію, кальцію, магнію, марганцю, заліза, міді, молібдену, цинку. Особливу роль у життєздатності сперміїв і їх відтворювальній властивості відіграють кальцій, цинк, мідь (Erohin et al., 1997).

Останніми роками відмічається інтенсивний розвиток і використання нових наноматеріалів, у тому числі наночастинок металів, що мають унікальні фізико-хімічні властивості, стабільність та біосумісність, які визначають їх високий потенціал з перспективою застосування у біології, біотехнології та гуманній і ветеринарній медицині (Reznichenko et al., 2006; Chen et al., 2008; Rozenfeld et al., 2008; Elder et al., 2008; Balabanov, 2009; Gusev, 2009; Chekman, 2009; Shimanovskiy, 2009; Plyuto et al., 2011; Chekman et al., 2012; Chekhman et al., 2016; Volodko, 2017).

Використання наночастинок визначається за їх унікальним розміром від 1 до 100 нм (1 міліардна метра) чи високим ступенем подрібнення, що істотно впливає на фізико-хімічні властивості, які дають їм можливість вступити у прямий контакт 3 різними хімічними сполуками органічної і неорганічної природи та структурами клітин, зокрема: протеїнами, ліпідами, нуклеїновими кислотами (Taniguchi, 1974; Roy et al., 2005; Lipin et al., 2006; Pul \& Ouens, 2009; Motornov et al., 2010; Chekman, 2015; Chekhman et al., 2016).

Е. П. Мінцюк і ін. (Mintsiuk et al., 2017; 2018), O. I. Горбатюк і ін. (Horbatiuk et al., 2017; 2018) повідомляють про стимулюючий вплив на ростові і розмножувальні процеси поживних середовищ для культивування бактерій C. Septicum та C. Perfringens типів A, B, C, Д за застосування наночастинок міді (CuNP) та золота (AuNP). Автори відмічають, що додавання нанопрепарату CuNP у концентрації від 0,1 до 0,031 мг/мл до складу середовища сприяє прискоренню росту і розмноження бактерій C. Septicum від 1,12 до 1,83 рази порівняно з контролем. Розроблено технологічний прийом із застосуванням наночастинок золота на етапі культивування C. Perfringens для виготовлення вакцин, що містять наночастинки металу.

У тваринництві і птахівництві наночастинки в основному застосовують як біодобавки, сорбенти мікотоксинів, мінеральні добавки (Elder et al., 2002; 2004; Elder et al., 2004; Lynch et al., 2006; Owino et al., 2008; Khomyn et al., 2015; Dvyliuk \& Kovalchuk, 2015). 
В. Ф. Федоренко і ін. (Fedorenko, 2008) повідомляють, що нанопрепарати із ембріональноплацентарних рідин і тканин за внутрішньом'язевого введення позитивно впливають на протікання обмінних процесів у організмі, підвищують імунітет та заплідненість корів на 8-10 відсотка.

На даний час найперспективнішими і найбільш затребуваними для біотехнології відтворення вважаються такі наночастинки металів,як ферум, цинк, купрум, манган, аргентум та їх оксидів контрольованого розміру в нанодіапазоні від 5 нм. до 60 нм. (Chen et al., 2007; Moskalenko et al., 2008; Laurent et al., 2008; Kovtun \& Verevkin, 2010; Avdeeva et al., 2014). Для одержання частинок нанометалів в основному застосовують два методи: фізичні подрібнення масивної речовини до частинок відповідних розмірів та хімічні - що базуються на відновленні іонів металів до атомів у розчині (Kuzmina et al., 2007; Chen et al., 2008).

Наведено, що при формуванні ембріонів свиней in vitro порід ландрас і велика біла за використання кріоконсервованих гамет із застосуванням у середовищах 0,001 \% концентрації високодисперсного кремнезему (ВДК) виживаність деконсервованих сперміїв зростає на $10 \%$, а кількість зародків на пізніх стадіях розвитку збільшується на 3,5-3,8 відсотка (Shcherbak et al., 2017).

C. I. Ковтун і ін. (Kovtun et al., 2018) виявлено, що використання 0,001 \% концентрації (ВДК) сахарози у складі середовища для in vitro культивування деконсервованих ооцит-кумулюсних комплексів (ОКК), отриманих із яєчників забитих клінічно здорових корів віком 3-5 років, сприяє підвищенню рівня дозрівання ооцитів до $76 \%$ та збільшенню кількості отриманих зародків запліднених in vitro до 33,3 відсотка.

M. М. Шараном і ін. (Sharan et al., 2018) експериментально доведено, що оптимальними дозами додавання наноцитратів мінералів до розрідженої сперми баранів-плідників, для підтримання виживання сперми на високому рівні, є 0,06 мг/л $\mathrm{Zn}^{2+} ; 0,01$ мг/л $\mathrm{Mn}^{2+}$ i 0,004 мг/л $\mathrm{Cu}^{2+}$ - наноцитратів у розчинених фосфатно-сольовим буфером еякулятах баранів. Автори не рекомендують використовувати вищі дози наноцитратів досліджуваних мікроелементів внаслідок зменшення тривалості виживання сперми.

Лабораторними дослідженнями проведеними I. I. Гевканом (Hevkan, 2014) виявлено, що додавання до 2,9 \% розчину цитрату натрію наночастинок срібла в оптимально визначених концентраціях 0,0050,05 мкг/мл, при розморожуванні сперми бугаїв, сприяє підвищенню активності деконсервованих сперміїв їх швидкості з прямолінійно-поступальним рухом та збільшенню терміну виживання при культивуванні у термостаті за температури $37^{\circ} \mathrm{C}$.

\section{Висновки}

Аналіз літературних джерел 3 розроблення та впровадження у виробництво синтетичних середовищ для кріоконсервування сперми баранів-плідників вказує про проведення вченими значної наукової та експериментальної роботи з вивчення і використання у них різних інгредієнтів з метою забезпечення життєздатності та відтворювальної властивості сперміїв.

Новий перспективний напрям відкривається перед дослідниками з можливістю вивчення та застосування у середовищах для кріоконсервування сперми самців, зокрема баранів-плідників наночастинок металів таких як: ферум, цинк, купрум, манган, аргентум та їх оксиди.

\section{References}

Avdeeva, L. Yu., Avramenko, E. A., \& Aksenenko, E. V. (2014). Nanorazmernyie sistemyi i nanomaterialyi: issledovaniya $\mathrm{v}$ Ukraine. Kiev: Akademperiodika (in Russian).

Balabanov, V. I. (2009). Nanotehnologii. Nauka buduschego. Izdatelstvo "Eksmo" (in Ukrainian).

Belous, A. M., Bondarenko, V. A., \& Gulevskiy, A. K. (1987). Molekulyarno-kletochnaya kontseptsiya kriopovrezhdeniya kletki: rol transmembrannyih defektov. Kriobiologiya, 2, 3-10 (in Russian).

Chekhman, I.S., Ulberh, Z., Rudenko, A., Bilous, S., \& Voronin, E. (2016). Pidtrymka stanu zdorovia liudei pislia chornobylskoi trahedii iz zastosuvanniam nanopreparativ Biodiversitg affer the Chernolyl Accident, 1, 51-54 (in Ukrainian).

Chekman, I. S. (2009). Nanochastynky: vlastyvosti ta perspektyvy zastosuvannia. Ukrainskyi biokhimichnyi zhurnal, 81(1), 122-129 (in Russian).

Chekman, I. S. (2015). Fiziolohichni ta farmakolohichni vlastyvosti nanorozmirnykh struktur. Fiziol. Zhurn., 61(6), 129-138 (in Ukrainian).

Chekman, I. S., Ulberh, Z. R., \& Malanchuk, V. O. (2012). Nanonauka, nanobiolohiia, nanofarmatsiia. K.: Polihraf plius (in Ukrainian).

Chen, D., Xi, T., \& Bai, J. (2007). Biological effects induced by nanosilver particles: in vivo study. Biomedical Materials, 2(3), 126-128. doi: 10.1088/17486041/2/3/S08.

Chen, J., Wang, J., Zhang, X., \& Jin, Y. (2008). Microwave-assisted green synthesis of silver nanoparticles by carboxymethyl cellulose sodium and silver nitrate. Materials chemistry and physics, 108(2-3), 421-424. doi: 10.1016/j.matchemphys.2007.10.019.

Chen, P. C., Mwakwari, S. C., \& Oyelere, A. K. (2008). Gold nanoparticles: from nanomedicine to nanosensing. Nanotechnology, science and applications, 1, 45. doi: 10.2147/nsa.s3707.

Davidenko, V. M. (1977). Vliyanie nekotoryih faktorov na kolichestvo spermyi pri zamorazhivanii. Nauchn. tehn. byul. Ukr. NIIZh stepnyih rayonov "Askaniya Nova", 1, 60-63 (in Russian).

Dvyliuk, I. I., \& Kovalchuk, I. I. (2015). Yakisni pokaznyky medu za umov zghodovuvannia nanoakvatsytrativ sribla i midi. Biolohiia tvaryn, 15, 162 (in Ukrainian).

Elder, A. C., Gelein, R., Azadniv, M., Frampton, M., Finkelstein, J., \& Oberdörster, G. (2002). Systemic interactions between inhaled ultrafine particles and endotoxin. Annals of Occupational Hygiene, 46(suppl_1), 231-234. doi: 10.1093/annhyg/46.suppl 1.231. 
Elder, A. C., Gelein, R., Azadniv, M., Frampton, M., Finkelstein, J., \& Oberdörster, G. (2004). Systemic effects of inhaled ultrafine particles in two compromised, aged rat strains. Inhalation toxicology, 16(6-7), 461-471. doi: 10.1080/08958370490439669.

Elder, J. B., Liu, C. Y., \& Apuzzo, M. L. (2008). Neurosurgery in the realm of $10-9$, part 2: applications of nanotechnology to neurosurgery-present and future. Neurosurgery., 62(2), 269-285. doi: 10.1227/01.neu. 0000315995.73269.c3.

Epishina, T. M. (2009). Povyishenie reproduktivnyih kachestv sviney i ovets (in Russian).

Erohin, A. S. (1994). Fiziologicheskie aspektyi kriorezistentnosti spermyi baranov i byikov. Diss. dokt. biol. nauk. Dubrovitsyi (in Russian).

Erohin, A. S., Epishina, T. M., \& Chernova, I. E. (1997). Problemyi kriokonservatsii semeni baranov. In Sovremennyie aspektyi selektsii, biotehnologii, informatizatsii $\mathrm{v}$ plemennom zhivotnovodstve, 233248 (in Russian).

Erohin, A. S., Kononov, V. P., \& Narizhnyiy, A. G. (1983). Deystvie mnogovalentnyih metallov na vosproizvoditelnuyu funktsiyu zhivotnyih. Dokladyi Vsesoyuznoy akademii selskohozyaystvenyih nauk im. VI Lenina, 5, 28-30 (in Russian).

Erohin, A. S., Petrova, T. I., \& Tkacheva, N. A. (1989). Ispolzovanie yaichnogo poroshka $\mathrm{V}$ sredah dlya zamorazhivaniya spermyi. Zootehniya, 8, 5-67 (in Russian).

Evans, R., \& Setchell, B. (1978). Association of exogenous phospholipids with spermatozoa. Journal of reproduction and fertility, 53, 357-362. doi: $10.1530 / j r f .0 .0530357$.

Fedorenko, V. F. (2008). Nanotehnologii i nanomaterialyi $\mathrm{V}$ agropromyishlennom komplekse. Selskohozyaystvennyie mashinyi i tehnologii, 6, 26-31 (in Russian).

Fornusek, L., Vetvicka, V., \& Petelikova, J. (1981). Ucinek redidel pro dlouhodobe uchovavani na akrozomy beranich spermii. Veterinarni medicinaCeskoslovenska akademie zemedelska Ustav vedeckotechnickych informaci pro zemedelstvi, 4, 213-221.

Gusev, A. I. (2009). Nanomaterialyi, nanostrukturyi, nanotehnologii. Uchebnoe posobie. Fizmatlit (in Russian).

Guskov, A. M., Dariy, G. E., \& Puzyina, G. I. (1993). Povyishenie reproduktivnoy sposobnosti zhivotnyih metodom ingibirovaniya perekisnogo okisleniya lipidov. Dokladyi Rosselhozakademii, 2, 71-73 (in Russian).

Hevkan, I. I. (2014). Vplyv riznykh kontsentratsii nanochastynok sribla $\mathrm{v}$ seredovyshchakh dlia rozridzhennia spermy buhaiv na rukhlyvist ta zhyttiezdatnist spermiiv. Rozvedennia i henetyka tvaryn, 48, 226-231 (in Ukrainian).

Holt, W. V., \& North, R. D. (1985). Determination of lipid composition and thermal phase transition temperature in an enriched plasma membrane fraction from ram spermatozoa. Reproduction, 1985, 73(1), 285-294. doi: 10.1530/jrf.0.0730285.
Horbatiuk, O. I., Andriiashchuk, V. O., Ryzhenko, H. F., Zhovnir, O. M., Rieznichenko, L. S., Dybkova, S. M., \& Tiutiun, S. M. (2017). Vplyv nanochastynok metaliv na aktyvizatsiiu metabolichnykh protsesiv u klitynakh C. perfringens typ A. Veterynarna biotekhnolohiia, 30, 47-56. doi: 10.31073/vet biotech30-05 (in Ukrainian).

Horbatiuk, O. I., Mintsiuk, Ye. P., Andriiashchuk, V. O., Ryzhenko, H. F., Zhovnir, O. M., Rieznichenko, L. S., \& Krylenko, S. Yu. (2018). Vyvchennia rivnia aktyvnosti membrannoi ATR-azy bakterii C. perfringens ta kryteriiv vplyvu na yikhni metabolichni protsesy nanochastynok zolota. Veterynarna biotekhnolohiia, 32(2), 100-112. doi: 10.31073/ vet biotech32(2)-12 (in Ukrainian).

Jones, R., \& Mann, T. R. R. (1973). Lipid peroxidation in spermatozoa. Proceedings of the Royal Society of London. Series B. Biological Sciences, 184(1074), 103-107. doi: 10.1098/rspb.1973.0035.

Kasimov, K. T., \& Ashimov, Zh. B. (1975). Oplodotvoryayuschaya sposobnost spermyi pri glubokim zamorazhivanii. Ovtsevodstvo, 8, 9-11 (in Russian).

Khomyn, M. M., Fedoruk, R. S., Khrabko, M. I., \& Kropyvka, S. Y. (2015). Vplyv nanoakvakhelatu yodu na biokhimichni pokaznyky moloka ta molochnu produktyvnist koriv u pershi misiatsi laktatsii. Naukovyi visnyk Lvivskoho natsionalnoho universytetu veterynarnoi medytsyny ta biotekhnolohii im. Gzhytskoho, 17(3), 243-249. http://nbuv.gov.ua/UJRN/nvlnu $2015 \quad 17 \quad 1(3) \quad 49$ (in Ukrainian).

Korban, N. V. (1988). Kriokonservatsiya spermyi hryaka. Kriokonservatsiya spermyi selskohozyaystvennyih zhivotnyih. Agropromizdat (in Russian).

Korban, N. V., Moroz, L. G., \& Shapiev, M. Sh. (1983). Otsenka kriorezistentnosti semeni hryakov po ustoychivosti $\mathrm{k}$ holodovomu udaru. Zhivotnovodstvo, 3, 44-45 (in Russian).

Kovtun, G. P., \& Verevkin, A. A. (2010). Nanomaterialyi: tehnologiya i materialovedeniya. Harkov fiz. tehn. Institut (in Russian).

Kovtun, S. I., Ziuziun, A. B., Shcherbak, O. V., \& Trotskyi, P. A. (2018). Vykorystannia nanobiotekhnolohichnykh metodiv dlia optymizatsii tekhnolohii kultyvuvannia ootsytiv koriv poza orhanizmom. Faktory eksperymentalnoi evoliutsii orhanizmiv, 22, 257-261. doi: 10.7124/FEEO.v22.958 (in Ukrainian),

Kurbatov, A. D., Platov, E. M., \& Korban, N. V. (1988). Kriokonservatsiya spermyi selskohozyaystvennyih zhivotnyih. L.: Agropromizdat (in Russian).

Kushnir, V. M. (1989). Perspektivyi razvitiya teorii i praktiki kriokonservatsii spermyi. Konkurentosposobnoe proizvodstvo produktsii zhivotnovodstva $\mathrm{v}$ Respublike Belorus: Sb. rabat Mezhd. nauch.-proizv. Konf, Zhodino, Belniizh, 146148 (in Russian).

Kuzmina, L. N., Zvidentsova, N. S., \& Kolesnikov, L. V. (2007). Poluchenie nanochastits serebra metodom himicheskogo vosstanovleniya. Zhurnal Rossiyskogo himicheskogo obschestva im. D. I. Mendeleeva, 30(8), 7-12 (in Russian). 
Laurent, S., Forge, D., Port, M., Roch, A., Robic, C., Vander Elst, L., \& Muller, R. N. (2008). Magnetic iron oxide nanoparticles: synthesis, stabilization, vectorization, physicochemical characterizations, and biological applications. Chemical reviews, 108(6), 2064-2110. doi: 10.1021/cr068445e.

Lipin, D. I., Chuan, Y. P., \& Neibert, M. (2006). Processing and in vitro assembly of virus-likeparticles. In Australian Research Council Nanotechnology Network International Conference on Nanoscience and Nanotechnology, 3-7.

Lynch, I., Cedervall, T., Lundqvist, M., Cabaleiro-Lago, C., Linse, S., \& Dawson, K. A. (2007). The nanoparticle-protein complex as a biological entity; a complex fluids and surface science challenge for the 21st century. Advances in colloid and interface science, 134, 167-174. doi: 10.1016/j.cis.2007.04.021.

Marinov, P. I. (1983). Izpitvane vliyanieto na razryaditeli sredrzhanie antioksidanti, verhu zamrazyaemostta na ovchi spermatozoidyi. Kriobiologiya na polovite kletki. Sofiya, 102-111 (in Russian).

Mesanos, P. (1977). Prezivatel spermii barana pri pouziti roznych druhov riedidiel pohlbokom zmarazeni v tekutom dusuku. Veter. Med., 22, 599-604 (in Russian).

Milovanov, V. K. (1959). Teoriya holodnogo udara zhivchikov mlekopitayuschih. Dokladyi VASHNIL, 73-79 (in Russian).

Milovanov, V. K. (1960). O holodovom udare zhivchikov selskohozyaystvennyih zhivotnyih. Zhivotnovodstvo, 1, 73-79 (in Russian).

Milovanov, V. K. (1970). O prirode kriogennyih povrezhdeniy zhivchikov barana. Vesti selskohozyaystvennoy nauki, 10, 86-93 (in Russian).

Milovanov, V. K., \& Sokolovskaya, I. I. (1980). Dlitelnoe hranenie semeni barana i novyie vozmozhnosti krupnomasshtabnoy selektsii v zhivotnovodstve. Vestnik selskohozyaystvennoy nauki, 2, 122-131 (in Russian).

Milovanov, V. K., Maksimov, O. B., \& Koltsova, E. A. (1983). Primenenie ehinohroma pri iskusstvennom osemenenii ovets. Zhivotnovodstvo, 9, 45-46 (in Russian).

Milovanov, V. K., Paramonov, L. I., \& Lizunkov, A. F. (1983). Ispolzovanii karatinoidov pri kriokonservatsii spermyi. Dokladyi VASHNIL, 11, 33-35 (in Russian).

Milovanov, V. K., Sokolovskaya, I. I., Oyvaydis, R. N., \& Abilov, A. M. (1983). Sreda dlya razbavleniya spermyi selskohozyaystvennyih zhivotnyih. Avtorskoe svidetelstvo № 1080819 (in Russian).

Milovanov, V. K., Vernavskaya, V. A., \& Zaytsev, V. V. (1989). Osobennosti zhivchikov barana i novyie sredi dlya semeni. Problemyi dolgosrochnogo hraneniya semeni baranov, Dubrovitsyi, 8-75 (in Russian).

Mintsiuk, Ye. P., Nychyk, S. A., \& Horbatiuk, O. I. (2017). Polipshennia yakosti zhyvylnoho seredovyshcha dlia anaerobiv za zastosuvannia nanochastynok midi. Materialy mizhnarodnoi naukovo-praktychnoi konferentsii molodykh vchenykh "Aktualniproblemy veterynarnoi biotekhnolohii ta infektsiinoi patolohii tvaryn", 55-56 (in Ukrainian).
Mintsiuk, Ye. P., Nychyk, S. A., Horbatiuk, O. I., Dybkova, S. M., Rieznichenko, L. S., Ryzhenko, H. F., \& Tiutiun, S. M. (2018). Udoskonalennia pozhyvnoho seredovyshcha dlia kultyvuvannia klostrydii nanochastynkamy midi (CuNP). Visnyk Dnipropetrovskoho derzhavnoho ahrarnoekonomichnoho universytetu, 1-2, 161-168 (in Ukrainian).

Mintsiuk, Ye. P., Nychyk, S. A., Horbatiuk, O. I., Ryzhenko, H. F., Andriiashchuk, V. O., Zhovnir, O. M., \& Dybkova, S. M. (2017). Sposib polipshennia rostovykh yakostei zhyvylnoho seredovyshcha dlia anaerobiv za zastosuvannia nanochastynok midi. Veterynarna biotekhnolohiia, 31, 110-119. doi: 10.31073/vet_biotech31-13 (in Ukrainian).

Moroz, L. G. (1990). Znachenie serosoderzhaschih soedineniy $\mathrm{v}$ ustoychivosti spermyi k zamorazhivaniyu. In Dokladyi VASHNIL, 9, 51-56 (in Russian).

Moskalenko, V. F., Rozenfeld, L. H., Movchan, B. O., \& Chekman, I. S. (2008). Nanotekhnolohii, nanomedytsyna, nanofarmokolohiia: stan, perspektyvy naukovykh doslidzhen, vprovadzhennia $\mathrm{v}$ medychnu praktyku. I nats. konhr. "Chelovek i lekarstvo" Ukraina, 167-168 (in Ukrainian).

Motornov, M., Roiter, Y., Tokarev, I., \& Minko, S. (2010). Stimuli-responsive nanoparticles, nanogels and capsules for integrated multifunctional intelligent systems. Progress in polymer science, 35(1-2), 174 211. doi: 10.1016/j.progpolymsci.2009.10.004.

Nauk, V. A. (1972). Sinteticheskoe sredyi dlya hraneniya semeni barana pri - 196 OS. TR. VIZhA. Biologiya vosproizvedeniya i iskusstvennoe osemenenie selskohozyaystvennyih zhivotnyih, 33, 224-227 (in Russian).

Nauk, V. A. (1991). Struktura i funktsiya spermiev s-h zhivotnyih pri kriokonservatsii. Kishinev: Shtiintsa (in Russian).

Nauk, V. A., \& Guskov, A. M. (1983). Osobennosti perekisnogo okisleniya lipidov pri zamorazhivanii spermyi byikov i hryakov-proizvoditeley. In Dokl. VASHNIL, 2, 27 (in Russian).

Ostashko, F. I. (1978). Glubokoe zamorazhivanie i dlitelnoe hranenie spermyi proizvoditeley. K.: Urozhay (in Russian).

Owino, J. H., Arotiba, O. A., Hendricks, N., Songa, E. A., Jahed, N., Waryo, T. T., \& Iwuoha, E. I. (2008). Electrochemical immunosensor based on polythionine/gold nanoparticles for the determination of aflatoxin B1. Sensors, 8(12), 8262-8274. doi: $10.3390 \% 2 \mathrm{Fs} 8128262$.

Platov, E. M. (1965). Zamorazhivanie semeni barana v laktozo-zheltochno-etilenglikolievoy sreda. Ovtsevodstvo, 9, 11-15 (in Russian).

Platov, E. M. (1973). Teoreticheskie i prakticheskie osnovyi zamorazhivaniya semeni proizvoditeley selskohozyaystvennyih zhivotnyih. Diss.... d-ra biol. nauk. Dubrovitsyi (in Russian).

Platov, E. M. (1986). Teoreticheskoe i prakticheskoe obosnovanie tehnologii zamorazhivaniya, ottaivaniya i ispolzovaniya spermyi baranov. Biologiya vosproizvedeniya $i$ tehnologiya iskusstvennoe 
osemenenie selskohozyaystvennyih zhivotnyih. Lispe Polyanyi, 7-17 (in Russian).

Platov, E. M. (1986). Zaschitnyie mehanizmyi spermyi baranov pri ekstremalnyih vozdeystviyah. Biologiya vosproizvedeniya i tehnologiya iskusstvennoe osemenenie selskohozyaystvennyih zhivotnyih. Lispe Polyanyi, 17-26 (in Russian).

Platov, E. M., \& Volkov, A. S. (1979). Effektivnost zamorazhivaniya spermyi baranov. Zootehniya, 5, 5356 (in Russian).

Platov, E. M., Avanov, N. Ya., \& Balashov, N. G. (1980). Zamorazhivanie spermyi baranov $\mathrm{v}$ sredah $\mathrm{s}$ polisaharidami. Ovtsevodstvo, 10, 38-39 (in Russian).

Platov, E. M., Deryazhentsev, V. I., \& Erohin, A. S. (1986). Metodicheskie rekomendatsii po tehnologii vzyatiya, glubokogo zamorazhivaniya i ispolzovaniya spermyi baranov-proizvoditeley pri iskusstvennyim osemenenii ovets. Moskva (in Russian).

Plyuto, I. V., Shpak, A., Zaporozhets, A. A., Zamurnyak, A., Tyazhkaya, N. P., Gorbik, P. P., \& Turov, V. V. (2011). Nanomaterialyi i nanokompozityi v meditsine, biologii i ekologii (in Ukrainian).

Pul, Ch. P., \& Ouens, F. D. (2009). Nanotehnologii, 336 (in Russian).

Reznichenko, L., Gruzina, T., Vember, V., Nemiro, S., \& Ulberg, Z. (2006). Nanoparticles of colloidal metals as perspective components for creation of metalcontaining probiotics. Abstracts of Ukrainian-German Symposium on Nanobiotechnology, 121.

Roy, I., Ohulchanskyy, T. Y., Bharali, D. J., Pudavar, H. E., Mistretta, R. A., Kaur, N., \& Prasad, P. N. (2005). Optical tracking of organically modified silica nanoparticles as DNA carriers: a nonviral, nanomedicine approach for gene delivery. Proceedings of the National Academy of Science, 102(2), 279-284. doi: 10.1073/pnas.0408039101.

Rozenfeld, L. H., Moskalenko, V. F., Chekman, I. S., \& Movchan, B. O. (2008). Nanotekhnolohii, nanomedytsyna: perspektyvy naukovykh doslidzhen ta vprovadzhennia yikh rezultativ u medychnu praktyku. Ukr. med. Chasopys, 67(5), 63-68 (in Russian).

Saacke, R. G., Amann, R. P., \& Marshall, C. E. (1968). Acrosomal cap abnormalities of sperm from subfertile bulls. Journal of Animal Science, 27(5), 1391-1400. doi: 10.2527/jas1968.2751391x.

Semyonova, V. A. (1987). Zaschtnyie svoystva otdelnyih faktorov zheltka kurinogo yaytsa pri zamorazhivanii semeni zhivotnyih (Doctoral dissertation, Vsesoyuznyiy ordena Trudovogo Krasnogo Znameni nauchno-issledovatelskiy institut zhivotnovodstva) (in Russian).

Sharan, M. M., Korniat, S. B., Yaremchuk, I. M., Kuzmina, N. V., Ostapiv, D. D., \& Chaikovska, O. I. (2018). Yakist spermiiv za dodavannia nanosuktsynativ metaliv $\mathrm{v}$ rozridzhenni eiakuliaty baraniv. NTV - DNDKI vet. preparativ ta kormovykh dobavok IBT NAAN, 19(2), 273-280. https://scivpjournal.com.ua/index.php/journal/issue/view/4 (in Ukrainian).

Sharan, M., Yaremchuk, I., Kornjat, S., Ostapiv, D., Kuzmina, N., \& Vlizlo, V. (2018). Quality of spermatozoa after addition of nanocitrates microelements in diluted ram ejaculates. Proceedings/Előadás Összefoglalók.

Shaydullin, I. N. (1977). Iskusstvennoe osemenenie ovets glubokim zamorazhivanii semenem. Zhivotnovodstvo, 8, 58-61 (in Russian).

Shaydullin, I. N. (1980). Usovershenstvovanie metoda zamorazhivaniya semeni baranov putem primeneniya antioksidantov. Avtoref. diss. kand. biol. Nauk, Dubrovitsyi (in Russian).

Shaydullin, I. N., \& Milovanov, V. K. (1981). Himicheskaya priroda antioksidantov i ih deystvie pri zamorazhivanii semeni baranov. Zootehniya, 8, 45-46 (in Russian).

Shcherbak, O. V., Halahan, N. P., Trotskyi, P. A., \& Kovtun, S. I. (2017). Zastosuvannia nanochastynok dioksydu kremniiu $\mathrm{v}$ tekhnolohii formuvannia embrioniv svynei in vitro. Nanosystemy, nanomaterialy, nanotekhnolohii, 15(2), 381-388 (in Russian).

Shimanovskiy, N. L. (2009). Nanotehnologii v sovremennoy farmakologii. Mezhdunarodnyiy meditsinskiy zhurnal, 1, 131-135 (in Russian).

Smith, K. L., Harrison, J. H., Hancock, D. D., Todhunter, D. A., \& Conrad, H. R. (1984). Effect of vitamin E and selenium supplementation on incidence of clinical mastitis and duration of clinical symptoms. Journal of dairy science, 67(6), 1293-1300. doi: 10.3168/jds.S0022-0302(84)81436-8.

Taniguchi, N. (1974). On the Basic Concept of'NanoTechnology. Proc. Intl. Conf. Prod. Eng. Tokyo, Japan Society of Precision Engineering, 2, 18-23.

Tervit, Y. R. (1984). The insemination of sheep with fresh or frozen semen. Proc.Z.Soc. Anim.Prod., 44, 11-13.

Varnavskiy, A. N., \& Vernavskaya, V. A. (1980). Osemenenii ovets zamorozhenyim semenem. Ovtsevodstvo, 11, 35 (in Russian).

Varnavskiy, A. N., Varnavskaya, V. A., \& Zaytsev, V. V. (1989). Novyie sredyi dlya zamorazhivaniya spermyi baranov. Zootehniya, 9, 46-49 (in Russian).

Vladimirov, Yu. A., \& Potapenko, A. Ya. (2006). Fizikohimicheskie osnovyi fotobiologicheskih protsessov. Drofa (in Russian).

Vladimirov, Yu. A., \& Proskurina, E. V. (2009). Svobodnyie radikalyi i kletochnaya hemilyuminestsentsiya. Uspehi biologicheskoy himii, 49(7), 341-388 (in Russian).

Vladimirov, Yu. A., \& Sherstnev, M. P. (1989). Hemilyuminestsentsiya kletok zhivotnyih. Itogi nauki i tehniki. Biofizika, 24, 3-172 (in Russian).

Volkov, A. S. (1974). Vliyanie chisla aktivnyih zhivchikov $\mathrm{v}$ ottayannom semeni na oplodotvoryaemost ovets. Zhivotnovodstvo, 10, 69-71 (in Russian).

Volodko, N. (2017). Bahatofunktsionalni nanomaterialy dlia biolohii i medytsyny: molekuliarnyi dyzain, syntez i zastosuvannia/za redaktsiieiu chlenakorespondenta NAN Ukrainy, diisnoho chlena NTSh Stoiky RS-Naukova dumka. Kyiv (in Ukrainian).

Watson, P. F., \& Anderson, W. J. (1983). Influence of butylated hydroxytoluene (BHT) on the viability of ram spermatozoa undergoing cold shock. Reproduction, 69(1), 229-235. doi: 10.1530/jrf.0.0690229. 
Wisser, D., \& Salamon, S. (1974). Fertility following insemination with deep frozen - thawed ram reconcentrated and inconcentrated ram semen. Austral. J. Bid. Sci., 2, 423-425.

Zheltobryuh, N. A. (1977). Primenenie saharnozheltochnyih sred dlya zamorazhivaniya spermyi barana. Tr. VNIIOK, 39, 111-118 (in Russian).

Zheltobryuh, N. A. (1986). Povyishenie effektivnosti osemeneniya ovets zamorozhennoy spermoy.
Materialyi nauchno-prakticheskoy konferentsii po ovtsevodstvu i kozovodstvu. Stavropol, 139-140 (in Russian).

Zheltobryuh, N. A., \& Ivahnenko, V. K. (1977). Sovershenstvovanie tehnologii zamorazhivaniya i ottaivaniya spermyi barana. Mat. nauch.- proiz. konf. VNINIK, 27-28 (in Russian). 